\title{
Microbiological study of Candida sp in HIV-seropositive patients with a subclinical diagnosis of oral candidiasis
}

\author{
Ana Laura Remédio Zeni Beretta*, Miriam de Magalhães Oliveira Levada, \\ Celso Luis Levada, Lindsay Felippe Baltel, Florence Zumbaio Mistro \\ Clinical Microbiology Department, Hermínio Ometto University Center, Avenue Dr. Maxímiliano Baruto 500, \\ Bloco A, Jardim Universitário, UNIARARAS, CEP 13607339 Araras, SP, Brazil
}

\begin{abstract}
Oral candidiasis is one of the opportunistic diseases most strongly associated with human immunodeficiency virus (HIV) infection. Several epidemiological surveys have demonstrated the prevalence of candidiasis in HIV-positive patients and have emphasized its importance as a marker of disease progression and as a predictor of the increase in immunodepression. The objective of the present study was to evaluate the frequency of Candida sp in the oral cavity of HIV-positive patients with low CD4 T lymphocyte count and a subclinical diagnosis of oral candidiasis. Sixty patients routinely seen at the Dental Clinic between August and November 2006 participated in the study. C. albicans was the species most frequently isolated, followed by C. krusei and C. tropicalis. In conclusion, since candidiasis is a highly frequent oral disease in HIV-infected patients, the diagnosis of this infection is of the utmost importance for early treatment, improving the quality of life of these patients.
\end{abstract}

Key words: oral candidiasis; Candida albicans; AIDS, HIV infection

\section{Introduction}

Oral candidiasis affects up to $90 \%$ of patients infected with human immunodeficiency virus (HIV) and is caused by yeast of the genus Candida. Among the 81 known species of the genus, C. albicans is the predominant species of the oral microbiota, accounting for 60 to $70 \%$ of all isolates, and causes infection under conditions that favor its growth $(14,23)$. Some of the non-albicans species are considered emerging pathogens, including C. dubliniensis, C. glabrata, C. tropicalis and C. krusei $(1,2,13,15,16,30)$. Studies have reported a reduced survival, discomfort, pain and halitosis in HIV-seropositive patients with oral candidiasis, with some type of treatment being necessary which may compromise even further the immune system of these patients $(5$, $7,19,22)$.

Infection with HIV and the occurrence of AIDS currently represent one of the major challenges of science $(1,24)$, a fact supporting the need for the prevention and treatment of diseases, as well as for the promotion and maintenance of oral health, in patients with HIV/AIDS $(4,24,25)$. An estimated 30.6 million people are infected with HIV worldwide. There is a predominance of males, with a male to female ratio of about 4:1, except for Central Africa where the gender ratio is practically 1:1. Similarly, young individuals are more frequently affected, with $90 \%$ of the patients presenting a mean age of 36.8 years (21).

Numerous oral manifestations have been described for HIV-infected patients and the most common are those resulting from fungal infections, specific and nonspecific bacterial infections, viral infections and neoplasms, and those of unknown etiology $(1,19)$.

The presence of oral lesions in patients with AIDS has been the subject of various studies since these oral manifestations represent the first signs and symptoms of disease (29). On the basis of these considerations, the objective of the present study was to evaluate the frequency of Candida sp in the oral cavity of HIV-infected patients seen at the Dental Clinic, and to compare the results with literature data.

\section{Patients and methods}

Patients - The sample consisted of $60 \mathrm{HIV}$-infected patients of both genders (age 20 to 60 years) with a CD4 T lymphocyte count below $400 / \mathrm{mm}^{3}$, seen at the Dental Clinic of Uniararas. The gender variable had no influence in the present study since the incidence of AIDS cases was the same among women and men.

Data collection - Data were obtained by anamnesis of the patients, analysis of the patients' records, clinical examination, and collection of biological material.

Material collection and species identification - Biological material was collected with a sterile swab from the oral cavity of 60 patients seeking routine dental care at the Dental Clinic of Uniararas, and all isolates obtained were identified at the Clinical Microbiology Department, Uniararas. The samples were carefully collected over a period of 4 months (August to November 2006) for the identification of Candida species in HIV-seropositive patients with a subclinical diagnosis of candidiasis. 
The laboratory diagnosis was initially based on the culture of test tubes containing $2 \%$ Sabouraud dextrose agar (SDA; Oxoid, Canada) supplemented with $0.1 \mathrm{mg} / \mathrm{mL}$ chloramphenicol, seeded in duplicate. The tubes were incubated at $35 \pm 1{ }^{\circ} \mathrm{C}$ and observed daily for 5 days. Smears were then prepared from the colonies grown and submitted to Gram staining (31). After microscopic observation of large, oval, Gram-positive cells, yeast-like elements with multipolar buds or eventual pseudo-hyphae with or without buds suggestive of Candida, the colonies were transferred to tubes containing liquid Sabouraud dextrose medium. C. albicans was identified by the germ tube test $(9,19)$.

The colonies grown on SDA were subcultured on Candida Chromagar $^{\mathbb{Q}}$ (Probac do Brasil ${ }^{\mathbb{Q}}$, São Paulo). This differential selective medium was used for the identification of yeast species according to the classical method of Kurtzman and Feelj (10). After incubation, C. albicans, C. krusei, C. tropicalis and other species without clinical importance could be identified.

Statistical analysis - The chi-square test was applied to correlate $C$. albicans isolates obtained from the oral cavity of HIV-positive patients with subclinical candidiasis with other Candida species, with the level of significance set at $\mathrm{p}<0.05$.

\section{Ethical issues}

The study was approved by the Research Ethics Committee of Hermínio Ometto University Center UNIARARAS, Araras, SP, Brazil (protocol 171/2006), according to resolution 196/96 of CONEP.

\section{Results}

Among the 60 patients from which samples were collected during intraoral examination, intraoral lesions were observed in $13.3 \%(\mathrm{n}=8)$ and $86.7 \%(\mathrm{n}=52)$ did not present any type of intraoral lesion (Table I).

Fifty-seven (95\%) of the 60 patients studied and diagnosed as HIV seropositive tested positive for yeast of the genus Candida, with eight (13.3\%) of them presenting clinical signs of candidiasis and $49(81.7 \%)$ subclinical signs. The three remaining patients presented subclinical signs and were colonized with bacteria (Table II). Among the eight patients with intraoral lesions, oral candidiasis was characterized by white plaques or reddish areas located on the tongue, gingiva, hard palate, labial commissures, and cheeks. C. albicans was isolated from five of these patients. This species was also isolated from $45(75 \%)$ patients without clinical signs (Table II). Only three of the 60 patients were not on antiretroviral treatment.

C. albicans was the most frequently detected species and was isolated from $50(83.3 \%)$ samples. $C$. krusei was isolated from four (6.7\%) samples, C. tropicalis from two (3.3\%), and another Candida species was detected in one (1.7\%). Bacteria were isolated from three (5\%) samples (Table III).

The results obtained were analyzed statistically, discussed and compared with literature data, generating a profile of the frequency of candidiasis caused mainly by $C$. albicans in HIV-seropositive patients (Table III).

\section{Discussion}

Studies have demonstrated the installation of a large number of fungal infections in HIV-positive patients as a result of marked alterations in immunological function mediated by $\mathrm{T}$ lymphocytes $(12,24)$. Among these pathogenic fungi, C. albicans plays a relevant role, with the frequency of infections caused by this species ranging from 3 to $30 \%$ and the mucosal forms being the earliest and most common manifestations (1, $27,29,30)$.

The frequency of oral candidiasis in HIV-positive patients varies among different studies, but the condition may affect up to $94 \%$ of infected individuals depending on the stage of infection and the population studied (3, 29). Candidiasis is a reliable marker of HIV disease progression (11).

According to Sonis et al. (28), candidiasis is the most expressive oral fungal infection in HIV-positive patients (four in five patients have candidiasis), with the frequency of oral candidiasis ranging from 20 to $90 \%$ in these patients. Greenspan (6) reported that $41 \%$ of patients with AIDS had candidiasis during the initial stage of the disease. According to Cavassani et al. (3), candidiasis and hairy leukoplakia were among the most frequent diseases observed in HIV-seropositive patients with a CD4+ count of less than 200 cells $/ \mathrm{mm}^{3}$.

In the present study, no intraoral lesions were observed in $86.7 \%$ of the patients with HIV. This finding was probably due to the maintenance of a strong immune system in the series studied.

According to the Brazilian Ministry of Health (18), the use of potent antiretroviral therapy drastically reduces the occurrence of opportunistic processes due to partial recovery of immunological function after the suppression of viremia and a decline in cell destruction caused by HIV.

In the present study, antiretroviral therapy may have been responsible for the lack of observation of clinical symptoms of candidiasis in some patients even in the presence of a low CD4+ T lymphocyte count, since antiretroviral therapy increases the immunological response and prevents disease progression. Most of 
these patients were already undergoing treatment, a fact that might explain the absence of lesions in 52 of the 60 HIV-seropositive patients studied (86.7\%).

Since antiretroviral drugs have prolonged the survival of patients, even that of immunosuppressed individuals, the diagnosis and treatment of diseases such as candidiasis represent a challenge that should not be underestimated.

The present results agree with those reported by Crocco et al. (4) who investigated the frequency of different Candida species in 100 patients. C. albicans was isolated from $76 \%$ of the patients, C. krusei from $19 \%$, and C. tropicals from $1 \%$, corresponding to a frequency of isolation of $96 \%$. A predominance of $C$. albicans has been reported in the literature among both immunocompetent and immunodepressed patients, with the frequency of isolation and prevalence of non-albicans species varying among different studies (8).

Menezes et al. (17), $80 \%$ of HIV-positive patients with or without characteristic lesions of oral candidiasis were positive for Candida, with C. albicans being identified in $65 \%, C$. tropicalis in $27.5 \%, C$. glabrata in $2.5 \%$, C. krusei in $2.5 \%$, and C. guilliermondii in $2.5 \%$. These authors and others suggested $C$. albicans to be the most frequent species in these patients.

A predominance of $C$. albicans was also observed in the present study, with a significant difference when compared to the other Candida species isolated. However, statistical comparison of our results with those reported by (17) showed no significant difference $(\mathrm{p}=0.125>0.05)$ between the different Candida species isolated.

C. albicans was the predominant yeast in the present study. Similar results have been reported by Silva (26) and Oliveira (20) who isolated C. albicans as the predominant species from the oral cavity of patients infected with HIV, as well as C. tropicalis, C. krusei and C. glabrata.

In the present study, the pathogenic Candida species found included C. albicans, C. tropicalis, $C$. krusei and another unidentified species. In addition, a predominance of C. albicans was observed in patients with or without candidiasis lesions. Thus, C. albicans was the most frequent yeast in patients infected with HIV.

One important fact is that the frequency of colonization with Candida species is higher among HIVpositive patients $(90.6 \%$ ) than among healthy individuals (common in up to $50 \%$ ) as a result of immunosuppression in the former which causes an imbalance in the oral microbiota.

Identification of the species causing candidiasis is important not only because of its epidemiological value but also because of the difference in the sensitivity to antimicrobial agents which may vary among species. In addition, knowledge of healthcare workers about oral manifestations in HIV-positive patients is relevant for the diagnosis, treatment and consequent improvement of the quality of life of these patients.

According to the literature, oral candidiasis is the most prevalent fungal infection among HIVseropositive patients, thus being an opportunistic infection of high prognostic value. Oral candidiasis may precede systemic manifestations in HIV-infected patients. This fact indicates an important role of the dentist in the prevention and early diagnosis of AIDS.

Since opportunistic fungal infections have been shown to be an important cause of mortality, studies like the present one are justified and essential for a better understanding of the interaction with the human oral environment in an attempt to prevent and control infections caused by these microorganisms.

Oral manifestations are frequently indicative of infection with HIV, thus representing an important diagnostic tool for the early detection of this infection. Professionals always need to be updated in order to fulfill these responsibilities and to be able to perform adequate dental treatment. Changes in this behavior require informative and educational aspects comprising knowledge about HIV infection as a priority in the training of dentistry students so that they become qualified professionals. The dentist plays a fundamental role in the prevention and early diagnosis of AIDS. These patients are potential customers in dental offices because the first manifestations of AIDS normally arise in the mouth. The role of the dentist is to promote and manage the oral health of HIV-seropositive patients in order to guarantee a better quality of life.

The present study shows the importance of interaction between the microbiology laboratory and the dental clinic to confirm the clinical diagnosis, thus providing adequate treatment to the patient.

\section{References}

[1]. Basseti M., Trecarichi E.M., Sanguinetti M., Bisio F., Posteraro B., Soro O. et al. (2007). Incidence, risk factors, and predictors of outcome of candidemia. Survey in 2 Italian university hospitals. Diag Microbiol Infect Dis.

[2]. Candido R.C., Azevedo R.V.P., Komesu M.C. (2009). Enzimotipagem de espécies do gênero Candida isoladas da cavidade bucal. Revista da Sociedade Brasileira de Medicina Tropical, v.33, n.5, p. 437-442, set./out.

[3]. Cavassani V.G.S. et al (2002). Candidíase oral como marcador de prognóstico em pacientes portadores do HIV. Revista Brasileira de Otorrinolaringologia, v. 68, n. 5, São Paulo, out.

[4]. Crocco E.I. et al (2004). Identificação de espécies de Candida e susceptibilidade antifúngica in vitro: estudo de 100 pacientes com candidíases superficiais. An. Bras. Dermatol, v.79, n.6, Rio de Janeiro, nov./dez.

[5]. Elazizi M.A. et al (2004) Interactions of Candida albicans with other Candida spp. and bacteria in the biofilms. Jappl. Microbiol., West Yorkshire, v. 96, n. 5, p. 10671073.

[6]. Greenspan D. (2004). Incidence of oral lesions in HIV-1-infected women: reduction with HAART. J Dent ., 83:145-50. 
[7]. Järvensivu A. et al (2004) Candida yeasts in chinic periodontitis tissues and subgingival microbial biofilms in vivo. Oral Diseases, London, v. 10, n. 2, p. 106112.

[8]. Jorge A.O.C. et al (1997). Presença de leveduras do gênero Candida na saliva de pacientes com diferentes fatores predisponentes e de indivíduos controle. Revista de Odontologia da Universidade de São Paulo, v.11, n.4, out./dez. p. 279-285

[9]. Koneman E., Allen J., Schreckenberger W. (2010). Diagnóstico microbiológico: texto e atlas colorido. 5th ed. São Paulo, MEDSI.

[10]. Kurtzman C.P., Feelj W. (1998). The yeasts. A taxonomic study. 4th ed. New York, Elsevier.

[11]. Lemos C.B., Coure H.A., Guimarães L.B., Bourguignon Filho A.M., Ganhoto R.M.A., Feitosa A.C.R. (2000). Diagnóstico das lesões periodontais associadas à infeçção pelo vírus HIV. Parte I. Considerações sobre sinais e sintomas. UFES Rev. Odontol., v. 2, n. 1, p. 28-36, jan/jun.

[12]. Lima O.C.C., Silveira F.R.X., Birman E.G. (1994). Manifestações bucais de origem infecciosa em pacientes HIV positivos ou com AIDS. Rev. ABO Nac, v. 2, n. 1 p. 28-32, fev./mar.

[13]. Lorenzo J.L. (2004). Microbiologia para o estudante de odontologia. 1st ed. Atheneu, São Paulo.

[14]. Lyon J.P., Resende M.A. (2007). Evaluation of adhesion to buccal epithelial cells in Candida species obtained from denture wearers after exposure to fluconazole. Mycoses. 50:21-24.

[15]. Marsh P., Martin M.V. (2005). Microbiologia Oral. 4th ed. São Paulo, Ed. Santos.

[16]. Menezes E.A. et al (2005). Freqüência e atividade enzimática de Candida albicans isoladas da mucosa bucal de crianças de uma creche da prefeitura de Fortaleza. Jornal Brasileiro de Patologia e Medicina Laboratorial. v. 41, n. 1, Rio de Janeiro, fev.

[17]. Menezes E.A. et al (2006). Freqüencia e atividade enzimática de Candida albicans isolado da cavidade oral de pacientes HIVpositivos em Fortaleza, Ceará. J. Bras. Patol. Med. Lab., vol.42, no. 4, ago, p.253-256.

[18]. Ministério da Saúde, Brasil. Secretaria de Assistência à Saúde (2008). Programa Nacional de Doenças Sexualmente Transmissíveis/Aids. Hepatite, Aids e Herpes na prática Odontológica. Brasília.

[19]. Moreira D. et al (2002). Candida spp. biotypes in the oral cavity of school children from different socioeconomic categories in Piracicaba - SP, Brazil. Pesq. Odontol. Bras., v. 15, n. 3, jul./set. p. 187-195.

[20]. Oliveira M.T.B. (1993). Estudo da mucosa bucal de pacientes imunocomprometidos no Estado do Rio Grande do Norte. São Paulo. PhD Thesis - Instituto de Ciências Biomédicas da Universidade de São Paulo.

[21]. Organização das Nações Unidas (ONU) (2005). Unaids AIDS in Africa: three different scenarios to 2025. Gênova.

[22]. O'Sullivan J.M., Jenkinson H.F., Cannon R.D. (2000). Adhesion of Candida albicans to oral streptococci is promoted by selective adsorption of salivary proteins to the streptococcal. Microbiology. 146 41-48.

[23]. Perazzo P.S.L. et al (2004). Candidíase laríngea isolada em paciente imunocompetente: Relato de caso clínico e revisão literária pertinente. Revista Brasileira de Otorrinolaringologia, v. 70, n. 2.

[24]. Back-Brito, G.N. et al. (2009) Frequency of Candida spp in the oral cavity of Brazilian HIV-positive patients and correlation with CD4 cell counts and viral load. Mycopathologia 167: 81-87.

[25]. Rossit A.R., Almeida M.T., Nogueira C.A., Oliveira J.G.C., Barbosa D.M., Moscardini A.C. et al (2007). Bacterial, yeast, parasitic, and viral enteropathogens in HIV-infected children from Sao Paulo State, Southeastern Brazil. Diagn Microbiol Infect Dis.57:59-66.

[26]. Silva, G. M. da, Silveira, Fernando, R. X, da, \& Pires, M. F. C. (2007). Adherence to HeLa cells, typing by killer toxins and susceptibility to antifungal agents of Candida dubliniensis strains. Brazilian Oral Research, 21(1), 87-91.

[27]. Soares L.F. et al (2002). Candidíase bucal em crianças infectadas pelo HIV - acompanhamento de quatro anos. Revista Brasileira de Odontologia, v. 59, n. 5, set./out., p. 341-343.

[28]. Sonis ST, Fazio RC, Fang L. Com aplicações bucais da quimioterapia do cancer. In: Sonis ST, Fazio RC, Fang L, Editores. Princípios e prática de medicina oral. $2^{a}$ ed. Rio de Janeiro: Guanabara Koogan ; 1999. Cap. 42.p. 358-81.

[29]. Souza L.B., Pinto L.P., Medeiros A.M.C. (2000). Manifestações orais em pacientes com AIDS em uma população brasileira. Pesq Odont Bras; 4:79-85.

[30]. Sullivan D.J., Moran G.P., Pinjon E., Al-Mosaid A., Stokes C., Vaughan C. et al (2004). Comparison of the epidemiology, drug resistance mechanisms, and virulence of Candida dubliniensis and Candida albicans. FEMS Yeast Res.4:369-376.

[31]. Ziarrusta G.B. (2002). Vulvovaginitis candidiásica. Rev Iberoa. Micol, v. 19, p. 22-4. 